\title{
Over-the-counter protein supplement resulting in impaired thyroxine absorption in a hypothyroid patient
}

\author{
P A D M Kumarathunga ${ }^{1}$, N S Kalupahana ${ }^{2}$ and C N Antonypillai ${ }^{1}$ \\ 'Diabetes and Endocrinology Unit, National Hospital Kandy, Kandy, Sri Lanka and 2Department of Physiology, Faculty \\ of Medicine, University of Peradeniya, Peradeniya, Sri Lanka
}

\author{
Correspondence \\ should be addressed \\ to P A D M Kumarathunga \\ Email \\ dineeshakumarathunga@ \\ gmail.com
}

\begin{abstract}
Summary
Whey protein is a popular dietary supplement that is claimed to provide multiple health benefits. It has been shown to delay gastric emptying and impair ileal nutrient absorption. Additionally, some of the other additives like papain enzyme, soy lecithin in these protein supplements could interfere with L-thyroxine absorption. There is no evidence in the literature for the effects of protein supplements on L-thyroxine absorption. Herein, we describe a case of a 34-yearold lady who was on endocrinology follow up for primary hypothyroidism with stable thyroid-stimulating hormone (TSH) levels within the normal range while on L-thyroxine with a dose of $125 \mu \mathrm{g}$ daily for the last 3 years, presenting with mild hypothyroid symptoms and elevated TSH level following a recent introduction of a protein supplement by her physical care adviser. Her treatment adherence and ingestion technique were good throughout, she was not on other medications or herbal remedies, there were no other changes in her food pattern or features suggestive of malabsorption, she was not pregnant, was taking the same L-thyroxine brand and TSH test was done from the routine lab. Since the only factor which could have contributed to the deranged TSH levels was the recent introduction of the whey protein supplement, we advised her to stop the protein supplement while continuing the same dose of L-thyroxine. Her TSH level was repeated in 6 weeks and was found to be normal $(1.7 \mathrm{mIU} / \mathrm{L})$. Our case report demonstrates that over-the-counter protein supplements could interfere with L-thyroxine absorption. Therefore, patients on L-thyroxine should be cautious when taking them.
\end{abstract}

\section{Learning points:}

- Over-the-counter protein supplements could interfere with oral L-thyroxine absorption.

- The underlying mechanism could be the effect of whey protein by delaying gastric emptying and reduced responsiveness of organic anion transporters in the ileum, and there may be a contribution from other additives like papain and soy lecithin present in these supplements.

- When there is an elevation of previously stable thyroid-stimulating hormone (TSH) value in a hypothyroid patient on oral L-thyroxine, the patient's assessment should include inquiring for a recent introduction of protein supplement, in the absence of other well-known risk factors.

- Discontinuation of protein supplement results in normalization of thyroid function tests.

- Patients on oral L-thyroxine should be cautious when taking over-the-counter protein supplementation. 


\section{Background}

In recent years, milk constituents have become recognized as functional foods, suggesting their use has a direct and measurable effect on health outcomes. Whey protein, a protein complex derived from milk is being promoted as a functional food with a number of health benefits (1). There is no evidence in the literature for the effects of protein supplements on L-thyroxine absorption and TSH levels in hypothyroid patients. Studies have shown that whey proteins delay gastric emptying time (2). Additionally, it may interfere with thyroid hormone transporters in the intestine $(3,4)$. Apart from that, papain and soy lecithin are included as additives in these supplements. While these mechanisms could be contributory to the impaired L-thyroxine absorption in the presence of the whey protein supplement, the exact mechanism is inconclusive. Our case study describes an unexpected effect of over-thecounter protein supplementation in a hypothyroid patient on oral L-thyroxine supplementation.

\section{Case presentation}

A 34-year-old lady was on endocrinology follow up for primary hypothyroidism. She was diagnosed with having Hashimoto's thyroiditis with mildly elevated antithyroperoxidase antibody titre since the last 3 years, 10 years following the remission of graves' disease at which time her thyroid receptor antibody level was negative. Her serum TSH levels were stable and within the normal range over the last 3 years while she was on oral tablet form of L-thyroxine with a dose of $125 \mu \mathrm{g}$ daily (1.66 ug/ $\mathrm{kg} /$ day dose for her weight of $75 \mathrm{~kg}$ ). Her last TSH value in April 2019 was $1.6 \mathrm{mIU} / \mathrm{L}$. After six monthly reviews, in November 2019, she had mild hypothyroid symptoms for the last 1 month, and her TSH was elevated to $12.5 \mathrm{mIU} / \mathrm{L}$. Her daily treatment adherence was good throughout and denied any recently missed doses. She adhered to proper ingestion technique with ingestion on an empty stomach and delaying breakfast for $1 \mathrm{~h}$ after taking her L-thyroxine. She did not have other comorbidities and was not on other prescribed or over-the-counter medications or herbal remedies, but she was recently prescribed a protein supplement by her physical care adviser for the purpose of improving the muscle strength. It was a whey protein blend with whey concentrate and whey isolate of which she was taking one serving (30 g with 22 g protein) daily 30 min after breakfast for the last 2 months. In addition to the whey protein concentrate and isolate, the supplement consisted of taurine, flavours (banana, cream), sodium chloride, dextrose, L-glutamine, thickener (xanthan gum), sweeteners (acesulfame K, sucralose), L-leucine, emulsifiersoy lecithin, digestive enzymes; bromelain and papain.

There was no change in her food pattern like an increase in consumption of coffee, soymilk or grapefruit juice except adding the whey protein supplement. She also denied a recent change of her L-thyroxine brand. She did not have any recent onset dyspepsia, vomiting, diarrhoea, loss of weight or anaemia. She did not have a period of amenorrhea suggestive of pregnancy or recent onset of significant weight gain. Her TSH test was done from the same lab which uses a chemiluminescent immune assay.

Since the only factor that could be elicited from detailed inquiry, which could have contributed to the recently deranged TSH, was the recent introduction of the whey protein supplement, we advised her to stop the protein supplement while continuing the same dose of L-thyroxine. Her TSH level was repeated in 6 weeks in January 2020 and was found to be normal (TSH - $1.7 \mathrm{mIU} / \mathrm{L}$ ).

\section{Investigation}

Her last TSH value in April 2019 was 1.6 mIU/L. In November 2019 , her TSH value elevated to $12.5 \mathrm{mIU} / \mathrm{L}$ after the recent initiation of the protein supplement. In January 2020, her TSH value returned to $1.7 \mathrm{mIU} / \mathrm{L}$ after stopping the protein supplement (Fig. 1).

\section{Outcome and follow up}

On her follow-up assessment in 6 months, the TSH value remained normal.

\section{Discussion}

Oral L-thyroxine is the mainstay of treatment of hypothyroidism and is being administered with a mean
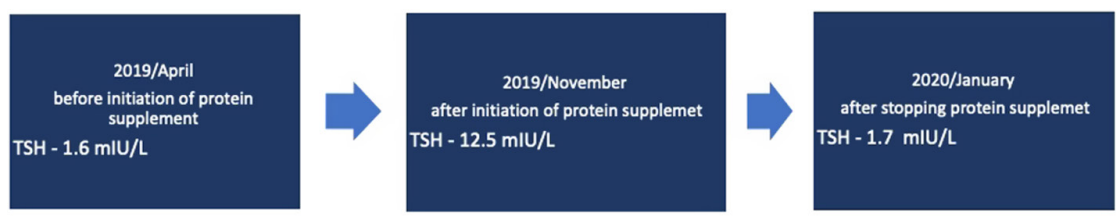

Figure 1

TSH variation over time. 
treatment dosage of $1.6-1.8 \mu \mathrm{g} / \mathrm{kg} / \mathrm{day}$ (5). About $60-80 \%$ of the oral dose of L-thyroxine is absorbed when taken on an empty stomach without interfering with food or medication. Absorption occurs within 2-3 h of ingestion and occurs mainly in the jejunum and ileum. Adequate gastric acidity is required to dissolve salt-based tablets including L-thyroxine allowing for proper intestinal absorption $(5,6,7)$. Patient's biochemical response to L-thyroxine treatment is determined by their serum TSH level (8), and TSH is the best marker for assessing the adequacy of treatment (5).

Factors that affect the ability to maintain TSH within the desired level include variable patient adherence, gastrointestinal conditions that affect L-thyroxine absorption, medication and food that interfere with L-thyroxine absorption, as well as the timing of meals, medications and physiological conditions that increase the demand for L-thyroxine and storage conditions that affect the integrity of the tablet $(7,8,9)$. Gastrointestinal malabsorption has been recently extensively reviewed by Camilla Virili et al. (7). Gastroparesis leading to delayed gastric emptying has also been recently recognized as a cause of persistently elevated TSH level in hypothyroidism $(7,10,11)$. The absorption of L-thyroxine can also be affected by different formulations due to various inactive ingredients present in different brands (12). Although uncommon, the possibility of analytical errors with 'sandwich' immune assays secondary to the interference of heterophilic antibodies that generate false-positive signal leading to falsely elevated TSH level should also be considered. But repeating TSH level using the same platform becoming normal will usually exclude assay interference (13).

The index patient was on $1.66 \mathrm{~g} / \mathrm{kg}(125 \mu \mathrm{g})$ thyroxine dose throughout, which is in the range for those with minimal residual thyroid function, but it is considered to restore TSH level in the normal range in most of the patients with hypothyroidism (5). She had good adherence to L-thyroxine with correct ingestion technique with a 1-hour gap before breakfast that facilitated the optimum absorption. There were no other features to suggest GI malabsorption or maldigestion condition, and she was not on any interfering medication or food. The basal thyroxine dose required by a patient depends on residual thyroid function, weight, lean body mass and to a lesser magnitude on patient's age, sex and menopausal state. Additionally, the bioequivalence of different thyroxine preparations may differ slightly between brands (5). Given the fact that she was maintaining the normal TSH level with the same dose and the brand of thyroxine, the basal upper normal range dose requirement in the presence of Hashimoto's thyroiditis could be due to her overweight or the difference in the bioequivalence of her thyroxine preparation.

For her recent presentation with elevated TSH level while on the same dose, brand and adherence, the only factor we could find that could have interfered with her L-thyroxine absorption was the protein supplement. After omitting the protein supplement from her diet, repeat TSH level returned back to normal confirming that the protein supplement interfered with her L-thyroxine absorption. To our knowledge, this is the first case report showing that an over-the-counter protein supplement can interfere with L-thyroxine absorption.

In recent years, milk constituents have become recognized as functional foods, suggesting their use has a direct and measurable effect on health outcomes. Whey protein, a protein complex derived from milk is being promoted as a functional food with number of health benefits (1). Whey proteins haveall theessential aminoacids in a high concentration, particularly high concentration of branched chain amino acids (especially leucine) which are important for tissue growth and repair and improved exercise performance and enhancement. The main components of whey protein include beta-lactoglobulin, alpha lactalbumin, lactoferrin, immunoglobulins, lactoperoxidase enzymes, glycomacropeptides, lactose and minerals (14).

Advances in processing techniques resulted in the development of several different finished whey products like whey protein concentrates (ranging from 80-95\% protein), reduced lactose whey, whey protein isolate (9095\% protein), demineralized whey, and hydrolyzed whey (1). These different commercially available whey protein products vary in the amount of protein, carbohydrates, immunoglobulins, lactose, minerals and fat that they contain and also the type and amount of additives. In addition to whey protein components, these protein supplements commonly contain other additives, where our patient's supplement had taurine, flavour (banana, cream), sodium chloride, dextrose, L-glutamine, thickener (xanthan gum), sweeteners (acesulfame K, sucralose), L-leucine, esterifier - soy lecithin, digestive enzyme blends - bromelain and papain (12 mg each per $30 \mathrm{~g}$ serving). In this case, impaired L-thyroxine absorption could be due to the effects of whey protein itself or the combined effect of the additives of the protein supplement.

Studies have shown that whey protein delays gastric emptying time. Stanstrup et al. have demonstrated that following a whey meal, plasma levels of acetaminophen and its metabolites rose markedly more slowly, and the 
maximum plasma concentration and the time taken to reach maximum plasma concentration fell significantly compared with other meals containing casein, gluten and fish protein (2). Oberoi et al. have clearly shown that there is a significant delay in gastric emptying following whey protein drink compared to controls found by measuring gastric antral area by 2D ultrasonography and calculating gastric emptying rates based on those measurements (15). Also, studies have shown that the gastric inhibitory peptide (GIP) which is released in response to food reaching the proximal small intestine was showing lower levels for the first hour after a whey protein meal, further supporting that whey protein delays gastric emptying (16). Delayed gastric emptying by medications and gastroparesis has clearly been shown to impair L-thyroxine absorption (10, 11, 17). The underlying mechanism may be sequestration of appropriately administered L-thyroxine dose with subsequent meals due to delayed gastric emptying, leading to decreased absorption (11). Though it has been suggested that lower intestinal motility increases the exposure time of thyroxine to the intestinal mucosa and promotes absorption (7), evidence is lacking for whey protein's effect on intestinal motility.

L-thyroxine hormone absorption can be reduced when it is co-administered with a variety of different substances, and studies have shown that concurrent cow's milk ingestion impairs thyroxine absorption likely attributable to the effect of its calcium and protein content (18). Though there was a time gap of $1.5 \mathrm{~h}$ between ingestion of thyroxine tablet and intake of whey protein supplement in the presented case, binding of whey protein to thyroxine leading to decreased thyroxine absorption is a possibility given the fact that the whole absorption process takes up to 2-3 $\mathrm{h}$ despite peak absorption occuring in the first 90 min (7). This could be exacerbated as a consequence of whey protein-induced delayed gastric emptying.

In addition, Kanishka $\mathrm{N}$ Nilaweera et al. suggested that whey protein reduces the responsiveness of ileal nutrient transporters to nutrient availability in lumen over time (3). The molecular mechanisms of L-thyroxine absorption in the gastrointestinal tract is still partially understood. Different thyroid hormone transporters are expressed in different organs mediating cellular uptake of thyroid hormones of which OATP2B1 (organic anion transporting polypeptide) being an important transporter expressed in enterocytes involving in thyroid hormone and anionic drug intestinal absorption. L-thyroxine drug/ food interactions may result from interaction with these transporters $(4,19)$. Grapefruit juice has been shown to inhibit this transporter in vitro and the effect of grapefruit juice in reduced L-thyroxine absorption is postulated due to this mechanism (20). Likewise, there could be a whey protein-mediated inhibitory effect on these thyroid hormone transporters interfering with L-thyroxine absorption, as its effect on ileal nutrient transporters. But this hypothesis needs further studies to prove it.

Among the additives in the protein supplement in the current study which could have an effect on L-thyroxine absorption include papain and soy lecithin. Soy lecithin is one of the most ubiquitous additives in the food supply, used primarily as an emulsifier. It contains about $35 \%$ soybean oil and 16\% phosphatidylcholine and the remaining percentage is other phospholipids and glycolipids (21). It usually makes up no more than $1 \%$ of processed foods. Thus, for a single serving of $30 \mathrm{~g}$ of the protein supplement, the estimated amount of soy protein ingested is $<0.1 \mathrm{~g}$. In the literature, persistent TSH elevation in hypothyroid patients in association with concomitant soy ingestion was associated with either soy formula, soy protein supplement or soy diet which contained a higher percentage of soy protein $(22,23,24)$. Apart from that, Persiani et al. have revealed that post-menopausal hypothyroid women who were given a dietary supplement containing $60 \mathrm{mg}$ of isoflavone, a phytoestrogen in soy protein that has claimed to interfere with thyroid functions (25), has not affected L-thyroxine absorption (26) where the isoflavone content in isolated soy protein is up to $1 \mathrm{mg} / \mathrm{g}$ of protein (27). Considering these, it is unlikely that the presence of soy lecithin being a major contributor to the impaired thyroxine absorption. Deiana et al. have reported a case of daily intake of a large amount of papaya fruit for 2 weeks (five to six fruits daily) resulting in impaired effectiveness of L-thyroxine therapy with the development of mild hypothyroidism (28). The possible mechanism they have suggested is a reduction of gastric acid secretion by papain acting directly on the gastric mucosa. Besides that, they have suggested possible effects from several other papaya substances as well. Thus, the papain enzyme included in the protein supplement could interfere with L-thyroxine absorption due to its effect on gastric acidity. However, this effect might be minimal with the amount of $12 \mathrm{mg}$ per serving where the approximate yield of papain is $5 \mathrm{~g}$ per unripen fruit (29). Lactose that could be present in variable fractions with whey products is not known to cause significant interference on L-thyroxine absorption in the absence of features of lactose intolerance.

Our case report shows that over-the-counter protein supplements could interfere with L-thyroxine absorption. The aforementioned could be considered as an explanatory hypothesis for the impaired L-thyroxine 
absorption in the presence of over-the-counter protein supplements. More studies are required to assess the exact effect of whey protein supplements on L-thyroxine absorption. Patients on L-thyroxine should be cautious when taking over-the-counter protein supplementation. Based on previously discussed facts, shifting the protein supplement to a later part of the day ( $>4 \mathrm{~h}$ since ingestion of thyroxine) would be an alternative to minimize its effects on L-thyroxine absorption, but it needs to be confirmed by further studies.

\section{Patient's perspective}

The patient stated that she never thought that the over-the-counter protein supplement could have interfered with her oral thyroxine absorption. But timely identification of it as the culprit for the derangement of her previously stable thyroid function made her restore the thyroid function without unnecessary dose increments and investigations. Additionally, she stated that she would be more cautious when going for an over-thecounter supplement while on replacement with important medication like thyroxine in the future.

\section{Declaration of interest}

The authors declare that there is no conflict of interest that could be perceived as prejudicing the impartiality of the research reported.

\section{Funding}

This research did not receive any specific grant from any funding agency in the public, commercial or not-for-profit sector.

\section{Patient consent}

Written informed consent for publication of her clinical details was obtained from the patient.

\section{Author contribution statement}

C N A proposed the original idea for this case report. P A D M K drafted the manuscript. C N A and N S K critically reviewed the manuscript. P A D M K revised the manuscript into its final version.

\section{References}

1 Marshall K. Therapeutic applications of whey protein. Alternative Medicine Review 20049 136-156.

2 Stanstrup J, Schou SS, Holmer-Jensen J, Hermansen K \& Dragsted LO. Whey protein delays gastric emptying and suppresses plasma fatty acids and their metabolites compared to casein, gluten, and fish protein. Journal of Proteome Research 201413 2396-2408. (https://doi. org/10.1021/pr401214w)

3 Nilaweera KN, Cabrera-Rubio R, Speakman JR, O'Connor PM, McAuliffe A, Guinane CM, Lawton EM, Crispie F, Aguilera M, Stanley M, et al. Whey protein effects on energy balance link the intestinal mechanisms of energy absorption with adiposity and hypothalamic neuropeptide gene expression. American Journal of
Physiology: Endocrinology and Metabolism 2017313 E1-E11. (https://doi. org/10.1152/ajpendo.00356.2016)

$4 \mathrm{Zu}$ Schwabedissen HEM, Ferreira C, Schaefer AM, Oufir M, Seibert I, Hamburger $\mathrm{M} \&$ Tirona RG. Thyroid hormones are transport substrates and transcriptional regulators of organic anion transporting polypeptide 2B1. Molecular Pharmacology 201894 700-712. (https:// doi.org/10.1124/mol.117.111161)

5 Jonklaas J, Bianco AC, Bauer AJ, Burman KD, Cappola AR, Celi FS, Cooper DS, Kim BW, Peeters RP, Rosenthal MS, et al. Guidelines for the treatment of hypothyroidism: prepared by the American Thyroid Association task force on thyroid hormone replacement. Thyroid 2014 24 1670-1751. (https://doi.org/10.1089/thy.2014.0028)

6 Lahner E, Conti L, Cicone F, Capriello S, Cazzato M, Centanni M, Annibale B \& Virili C. Thyro-entero-gastric autoimmunity: pathophysiology and implications for patient management. Best Practice and Research: Clinical Endocrinology and Metabolism 202034 101373. (https://doi.org/10.1016/j.beem.2019.101373)

7 Virili C, Antonelli A, Santaguida MG, Benvenga S \& Centanni M. Gastrointestinal malabsorption of thyroxine. Endocrine Reviews 2019 40 118-136. (https://doi.org/10.1210/er.2018-00168)

8 Bach-Huynh TG, Nayak B, Loh J, Soldin S \& Jonklaas J. Timing of levothyroxine administration affects serum thyrotropin concentration. Journal of Clinical Endocrinology and Metabolism 2009 94 3905-3912. (https://doi.org/10.1210/jc.2009-0860)

9 Centanni M, Benvenga S \& Sachmechi I. Diagnosis and management of treatment-refractory hypothyroidism: an expert consensus report. Journal of Endocrinological Investigation 201740 1289-1301. (https:// doi.org/10.1007/s40618-017-0706-y)

10 Khraisha OS, Al-Madani MM, Peiris AN \& Paul TK. Gastroparesis - a novel cause of persistent thyroid stimulating hormone elevation in hypothyroidism. Journal of the Louisiana State Medical Society 2015167 47-49.

11 Reardon DP \& Yoo PS. Levothyroxine tablet malabsorption associated with gastroparesis corrected with gelatin capsule formulation. Case Reports in Endocrinology 20162016 e1316724. (available at: https ://www.hindawi.com/journals/crie/2016/1316724/). (https://doi. org/10.1155/2016/1316724)

12 Blakesley V, Awni W, Locke C, Ludden T, Granneman GR \& Braverman LE. Are bioequivalence studies of levothyroxine sodium formulations in euthyroid volunteers reliable? Thyroid 200414 191-200. (https://doi.org/10.1089/105072504773297867)

13 Razvi S, Bhana S \& Mrabeti S. Challenges in interpreting thyroid stimulating hormone results in the diagnosis of thyroid dysfunction. Journal of Thyroid Research 20192019 1-8. (available at: https:// www.hindawi.com/journals/jtr/2019/4106816/). (https://doi. org/10.1155/2019/4106816)

14 Walzem RL, Dillard CJ \& German JB. Whey components: millennia of evolution create functionalities for mammalian nutrition: what we know and what we may be overlooking. Critical Reviews in Food Science and Nutrition 200242 353-375. (https://doi. org/10.1080/10408690290825574)

15 Oberoi A, Giezenaar C, Jensen C, Lange K, Hausken T, Jones KL, Horowitz M, Chapman I \& Soenen S. Acute effects of whey protein on energy intake, appetite and gastric emptying in younger and older, obese men. Nutrition and Diabetes 202010 37. (available at: https:// www.ncbi.nlm.nih.gov/pmc/articles/PMC7531014/). (https://doi. org/10.1038/s41387-020-00139-8)

16 Holmer-Jensen J, Mortensen LS, Astrup A, de Vrese M, Holst JJ, Thomsen C \& Hermansen K. Acute differential effects of dietary protein quality on postprandial lipemia in obese non-diabetic subjects. Nutrition Research 201333 34-40. (https://doi.org/10.1016/j.nutres.2012.11.004)

17 Kim PJ \& Sachmechi I. Levothyroxine malabsorption induced by diabetic gastroparesis exacerbated during pregnancies: effect of intramuscular levothyroxine injections and levothyroxine soft gel capsules. AACE Clinical CASE Reports 20151 e73-e78. (https://doi. org/10.4158/EP14051.CR) 
Endocrinology

Diabetes \& Metabolism

CASE REPORTS
P A D M Kumarathunga and

others
Protein supplement and

thyroxine absorption
ID: 21-0070; July 2021

DOI: 10.1530/EDM-21-0070
18 Chon DA, Reisman T, Weinreb JE, Hershman JM \& Leung AM. Concurrent milk ingestion decreases absorption of levothyroxine. Thyroid 201828 454-457. (https://doi.org/10.1089/thy.2017.0428)

19 Kinne A, Schülein R \& Krause G. Primary and secondary thyroid hormone transporters. Thyroid Research 20114 S7. (https://doi. org/10.1186/1756-6614-4-S1-S7)

20 Satoh H, Yamashita F, Tsujimoto M, Murakami H, Koyabu N, Ohtani H \& Sawada Y. Citrus juices inhibit the function of human organic anion-transporting polypeptide Oatp-B. Drug Metabolism and Disposition 200533 518-523. (https://doi.org/10.1124/ dmd.104.002337)

21 Mounts TL. Chemical and physical effects of processing fats and oils Journal of the American Oil Chemists' Society 198158 51A-54A. (https:// doi.org/10.1007/BF02666073)

22 Bell DS \& Ovalle F. Use of soy protein supplement and resultant need for increased dose of levothyroxine. Endocrine Practice 20017 193-194. (https://doi.org/10.4158/EP.7.3.193)

23 Conrad SC, Chiu H \& Silverman BL. Soy formula complicates management of congenital hypothyroidism. Archives of Disease in Childhood 200489 37-40. (https://doi.org/10.1136/adc.2002.009365)

24 Jabbar MA, Larrea J \& Shaw RA. Abnormal thyroid function tests in infants with congenital hypothyroidism: the influence of soy-based formula. Journal of the American College of Nutrition 199716 280-282. (https://doi.org/10.1080/07315724.1997.10718686)

25 Wiesner A, Gajewska D \& Paśko P. Levothyroxine interactions with food and dietary supplements - a systematic review. Pharmaceuticals 202114 206. (https://doi.org/10.3390/ph14030206)

26 Persiani S, Sala F, Manzotti C, Colovic M, Zangarini M, Donazzolo Y, Barbetta B, Vitalini C, Giacovelli G, Benvenuti C, et al. Evaluation of levothyroxine bioavailability after oral administration of a fixed combination of soy isoflavones in post-menopausal female volunteers. Drug Research 201666 136-140. (https://doi. org/10.1055/s-0035-1555784)

27 Sacks FM, Lichtenstein A, Van Horn L, Harris W, Kris-Etherton P, Winston M \& American Heart Association Nutrition Committee. Soy protein, isoflavones, and cardiovascular health: an American Heart Association Science Advisory for Professionals from the Nutrition Committee. Circulation 2006113 1034-1044. (https://doi.org/10.1161/ CIRCULATIONAHA.106.171052)

28 Deiana L, Marini S \& Mariotti S. Ingestion of large amounts of papaya fruit and impaired effectiveness of levothyroxine therapy. Endocrine Practice 201218 98-100. (https://doi.org/10.4158/EP11233.CO)

29 pap003.pdf [Internet]. [cited $2020 \mathrm{Apr} 13]$. (available at: http://nhb. gov.in/pdf/fruits/papaya/pap003.pdf)

Received in final form 13 June 2021

Accepted 21 June 2021 